\title{
Extension of summer (June-August) temperature records for northern Inner Mongolia (1715-2008), China using tree rings
}

\author{
Zhenju Chen $^{\mathrm{a}, \mathrm{b}, *}$, Xianliang Zhang ${ }^{\mathrm{a}, \mathrm{c}}$, Xingyuan He ${ }^{\mathrm{a}, \mathrm{d}}$, Nicole K. Davi ${ }^{\mathrm{e}}$, Mingxing Cui ${ }^{\mathrm{d}}$, Junjie Peng ${ }^{\mathrm{a}}$ \\ a State Key Laboratory of Forest and Soil Ecology, Institute of Applied Ecology, Chinese Academy of Sciences, Shenyang 110164, China \\ ${ }^{\mathrm{b}}$ Research Station of Liaohe-River Plain Forest Ecosystem, Shenyang Agriculture University, Changtu 112500, China \\ ${ }^{c}$ Institute of Atmospheric Physics, Chinese Academy of Sciences, Beijing 100029, China \\ ${ }^{\mathrm{d}}$ Northeast Institute of Geography and Agroecology, Chinese Academy of Sciences, Changchun 130012, China \\ ${ }^{\mathrm{e}}$ Tree-Ring Laboratory, Lamont-Doherty Earth Observatory, Columbia University, NY 10964, USA
}

\section{A R T I C L E I N F O}

Article history:

Available online $\mathrm{xxx}$

\begin{abstract}
A B S T R A C T
This paper presents a spatially and temporally improved reconstruction of mean summer (June-August) temperature derived from tree-ring width data of Dahurian larch (Larix gmelinii Rupr.) from the northern Great Xing'an Mountains, Northeast China. Three new chronologies were added to the original 2011 reconstruction, and the reconstruction extended back to AD 1715. The reconstruction was generated using a simple linear regression method, verified by independent meteorological data, and accounts for $47.0 \%$ of the actual temperature variance during the common period (1957-2008). The reconstruction captures decadal and century-scale regional temperature variability, such as cold decades (1940s, 1930s, 1790 s, 1950 s and 1850s), warm decades (2000s, 1870s, 1750s, 1980s and 1840s), a cold half-century (ca. 1750-1799), and a warm half-century (ca. 1900-1949). It also reveals slightly higher frequency of cold years $(20.4 \%)$ than warm years $(18.0 \%)$, and a recent warming trend. Compared to the original 2011 reconstruction, this reconstruction has lower inter-annual temperature variability, high explained variance and high representativeness of regional climate. The reconstruction also correlates with the East Asian Monsoon and the Pacific Ocean signals, and indicates the feasibility of using tree rings from high latitude Northeast China to reconstruct summer temperature in permafrost forest environments.
\end{abstract}

(c) 2012 Elsevier Ltd and INQUA. All rights reserved.

\section{Introduction}

To understand how climate variability affects ecosystem functions and natural resource management, long-term, high-resolution paleoclimate records are of fundamental importance. Climate variability patterns over the Mongolian Plateau in recent decades have become a serious concern due to their significant impacts on regional ecosystems and people (e.g. Jacoby et al., 1996, 2003; Liu et al., 2003, 2007, 2010; Yatagai, 2003; Davi et al., 2006; Liang et al., 2007; Li et al., 2009). However, meteorological records for this region are particularly sparse and are not suitable to fully understand long-term and large-scale climate change. Even though numerous climate reconstructions have been published about the region over the past several decades, there is still an urgent need to add paleoclimate studies in northeastern China. Improved quantitative information, which can be derived from proxy records such

\footnotetext{
* Corresponding author. State Key Laboratory of Forest and Soil Ecology, Institute of Applied Ecology, Chinese Academy of Sciences, Shenyang 110164, China.

E-mail address: zhenjuchen@hotmail.com (Z. Chen).
}

as tree rings, is needed to better understand climate change and describe long-term variations in climatological means, extremes, and trends, and to test for evidence of cyclical variations.

Tree rings are one of the most important proxies for studying past climate due to their high time resolution and precise dating (Fritts, 1976). Recent studies of tree rings have documented many climate fluctuations in the world, but existing regional tree-ring proxy temperature and precipitation records from Northeast China and vicinity are limited to only the past few centuries in many cases and do not capture regional-scale climate variability (Liu et al., 2003, 2007, 2010; Liang et al., 2007; Li et al., 2009; Zhu et al., 2009; Zhang et al., 2011a). Previous studies provide some estimations of temperature variability (e.g., Jacoby et al., 1996, 2003; Shao and Wu, 1997; D'Arrigo et al., 2001; Zhu et al., 2009; Zhang et al., 2011a), but there are only a few documented tree-ring based temperature reconstructions available for southern Northeast China (Shao and Wu, 1997; Zhu et al., 2009), and only one is available from the permafrost-dominated northern regions (Zhang et al., 2011a) (hereafter, "original 2011 model"). Furthermore, the permafrost-influenced forest ecosystem, particularly the radial growth of regional dominant species, Dahurian larch, is quite 
sensitive to changes in temperature (Vaganov et al., 1996; Kääb and Chiarle, 2007; Zyryanova et al., 2007; Vaganov and Kirdyanov, 2010), and incremental changes in temperature are a welldocumented cause of permafrost degradation during the 20th century (Zhou et al., 2002; Osterkamp, 2005; Harris et al., 2009).

The Pacific Ocean regime significantly affects moisture condition over much of Mongolian Plateau and vicinity (IPCC, 2007; Li et al., 2009; Liu et al., 2009; Chen et al., 2012), especially its characteristic modes of atmosphere-ocean circulation including the Asian monsoon (Li and Zeng, 2003) and the Pacific Decadal Oscillation (PDO) (Mantua and Hare, 2002). However, the long-term linkage between Pacific Ocean regimes and cold/warm modes in the remote mountain regions of Inner Mongolia has yet to be determined.

Thus, in order to contextualize recent and future temperature changes and increase spatial and temporal coverage of the original 2011 model, this study combined tree rings of different sites from northern Great Xing'an Mountains, Inner Mongolia and demonstrated the fidelity of the model to capture temperature variability, particularly variations in summer temperature amplitude on an inter-annual to centennial timescale. The goals of this study are to: (1) identify the leading summer temperature patterns for northeastern China through updating and improving the original 2011 model, (2) use the updated treering data to reconstruct regional cold and warm modes, and (3) investigate the variability of the reconstruction and its linkages with the East Asia monsoon and tropic Pacific Ocean climate regimes.

\section{Materials and methods}

\subsection{Study area and tree-ring data}

The study area is located in the western Great Xing'an Mountains in northern Inner Mongolia, a dividing zone of dry/wet and cold/warm climate in northeastern China and a typical monsoon boundary zone (continental monsoon climate) (Fig. 1). The sampling sites in Genhe (three sites, $800 \mathrm{~m}-1000 \mathrm{~m}$ a.s.l.) and Mo'erdaoga (one site, $840 \mathrm{~m}$ a.s.l) (Fig. 1) are all located in the permafrost region (Jin et al., 2000; Sun et al., 2007). The permafrost and climate of this region was described by Zhang et al. (2011a) and also in Figs. 1 and 2 of this paper. Tree growth is strongly affected by frozen soil in this region, e.g. Dahurian larch, the dominant species, has adapted to the tough permafrost environment, but grows slowly due to limitations imposed by the frozen soil.

The tree-ring sites were selected from high-latitude permafrost sites in mountain ranges where old-growth forests and temperature-sensitive trees are present (Kirdyanov et al., 2003; Vaganov and Kirdyanov, 2010). A total of 170 increment cores (1-2 per tree) were extracted at breast height from 87 Dahurian larch trees (66 from Genhe and 21 from Mo'erdaoga) growing on the permafrost across northern Inner Mongolia (Fig. 1). Three new chronologies have been developed for this study, and the Mo'erdaoga site used in the previous study (Zhang et al., 2011a). Conventional dendrochronological techniques (Fritts, 1976; Holmes, 1983; Cook, 1985) were used to develop ring-width chronologies. The samples were mounted, air-dried and sanded (Stokes and Smiley, 1968). Tree rings were visually crossdated, and then each ring-width was measured with a LINTAB5 measuring system with a resolution of $0.001 \mathrm{~mm}$. Dating and measurement errors were further checked by the computer program COFECHA (Holmes, 1983). The samples from three sites in Genhe crossdated well (average measurement series intercorrelation is $r=0.511$ ). The three sites at Genhe are roughly 2-3 $\mathrm{km}$ apart and are located at similar elevations with similar

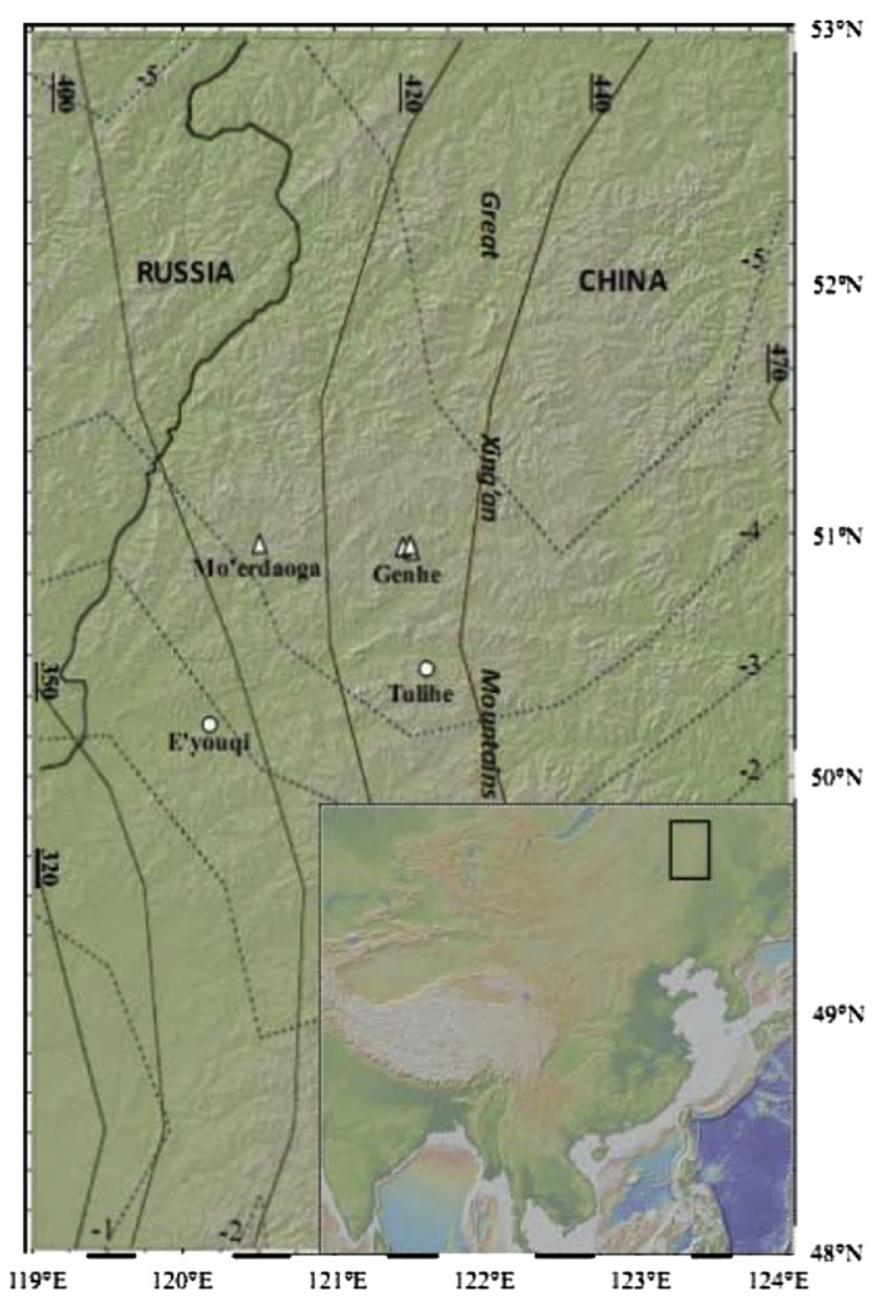

Fig. 1. Map showing the locations of the 4 tree-ring sites (triangles) and the 2 meteorological stations (circles). Small inset map shows location of sites in Asia. The contours with labels and underlined contour labels, respectively denote the mean January-December averaged CRU TS3.1 $1^{\circ} \times 1^{\circ}$ gridpoint of temperatures $\left({ }^{\circ} \mathrm{C}\right)$ and mean January-December total CRU TS3.1 $1^{\circ} \times 1^{\circ}$ gridpoint of precipitation (mm/year) from 1957 to 2008 .

microenvironments, indicating a homogeneous common influence of local climate (Table 1 ). Therefore, all measurements of the three Genhe sites were pooled to develop a composite ring-width chronology.

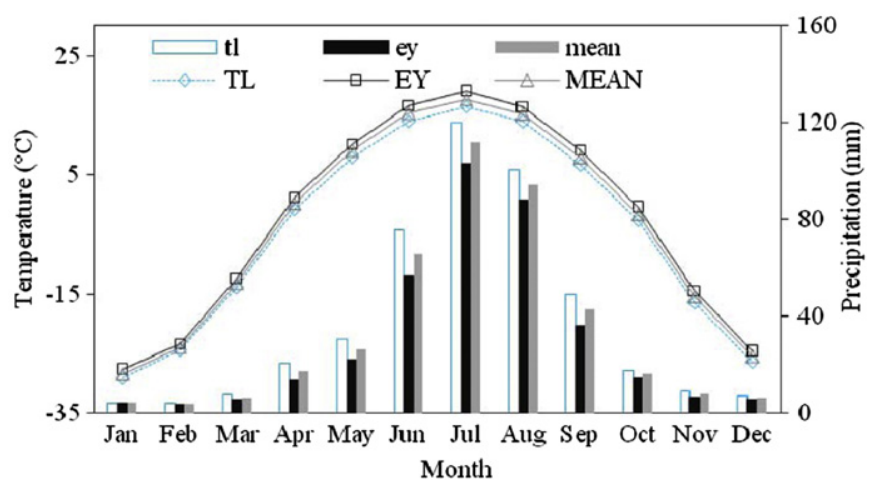

Fig. 2. Monthly mean temperatures (curves) and monthly total precipitation (bars) based on available records from the Tulihe (tl/TL) and Eyouqi (ey/EY) meteorological stations and their average (mean/MEAN) during the common period of 1957-2008. 
Table 1

Statistics for Genhe and Mo'erdaoga standard chronologies and their arithmetic average (mean).

\begin{tabular}{|c|c|c|c|c|c|c|c|c|}
\hline & Length (year) & SD & MS & AC1 & Skew & Kurtosis & $\mathrm{EPS}(>0.85)$ & $\mathrm{SSS}>0.75$ \\
\hline Mo'erdaoga & $294(1715-2008)$ & 0.250 & 0.139 & 0.720 & 1.122 & 6.059 & $0.910(1742)$ & 1723 \\
\hline Genhe & $312(1697-2008)$ & 0.197 & 0.146 & 0.556 & 0.229 & 3.386 & 0.969 (1714) & 1714 \\
\hline Mean & $312(1697-2008)$ & 0.192 & 0.126 & 0.648 & 0.753 & 1.580 & & 1715 \\
\hline
\end{tabular}

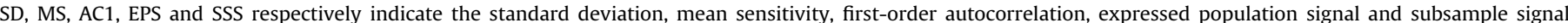

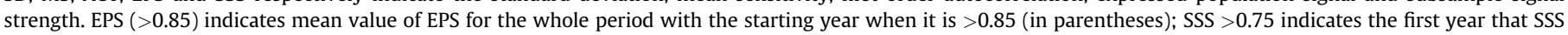
exceeds 0.75 .

In order to preserve as much low-frequency signal as possible and reduce serious end distortions in these time series, most of the raw tree-ring measurements were detrended using straight lines or negative exponential curves after comparing the results of different detrending methods. Tree-ring series with significant non-climatic disturbances, that could not be fitted well by conservative curves, were detrended by a rigid cubic spline curve with a $50 \%$ cutoff equal to 2/3 of each series length. Based on a 20-year window, the interseries correlation (rBar) and expressed population signal (EPS), with a threshold value of 0.85 , were employed to evaluate the timevarying signal strength over the length of the chronology (Wigley et al., 1984). The tree-ring indices were averaged together to generate a Standard chronology (STD) for each region using the program ARSTAN (Cook and Holmes, 1986). Several descriptive statistics commonly used in dendrochronology, including the standard deviation (SD), mean sensitivity (MS), first-order autocorrelation (AC1), and the coefficients of skewness and kurtosis were also calculated. Thereafter, the STD for three sites in Genhe and one site in Mo'erdaoga across northern Inner Mongolia, which share a common period from 1715 to 2008, were developed (Table 1). The STD for Genhe and STD for Mo'erdaoga are significantly correlated $\left(r_{1715-2008}=0.535, p<0.001\right)$ and the first principal component (PC1) explains $76.76 \%$ of the variance, indicating homogeneity of forest stands and regional environments (Fig. 3). Thus, a PC1-score time series representing a regional profile of Dahurian larch radial growth could be extracted from the Genhe and Mo'erdaoga sites, and a robust composite STD, composed of 170 cores, could be built through arithmetic average (Fig. 3 ).

\subsection{Climate data}

The meteorological records were obtained from the China Meteorological Data Sharing Service System (http://cdc.cma.gov. $\mathrm{cn} /$ ). The longest (52 years in length) and most continuous meteorological records from the 2 nearest meteorological stations were selected to model the regional climate signals in tree rings: Tulihe $\left(50^{\circ} 29^{\prime} \mathrm{N}, 121^{\circ} 41^{\prime} \mathrm{E}, 732.6 \mathrm{~m}\right.$ a.s.l. $)$ and E'ergunayouqi

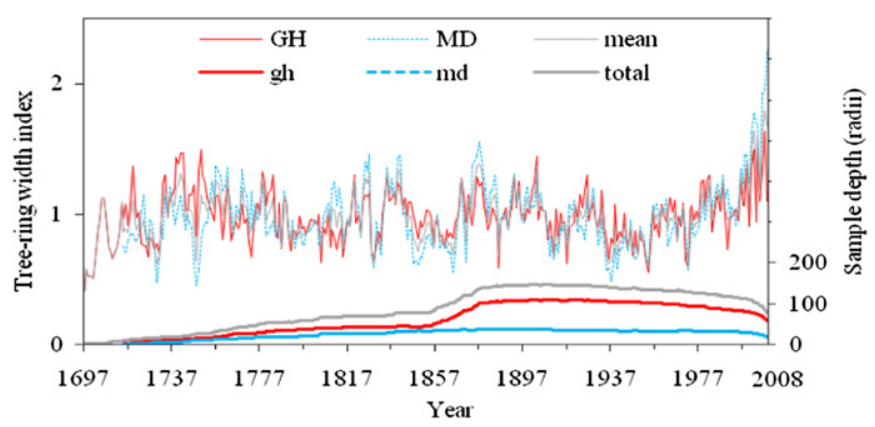

Fig. 3. Standard chronologies and the corresponding sample size. GH (Genhe) and MD (Mo'erdaoga) indicate individual Standard chronologies (refer to Table 1), and their corresponding sample depth gh and md; mean is composite chronology derived from arithmetic average of $\mathrm{GH}$ and $\mathrm{MD}$, and total is their total sample depth.
(E'youqi, $50^{\circ} 15^{\prime} \mathrm{N}, 120^{\circ} 11^{\prime} \mathrm{E}, 581.4 \mathrm{~m}$ a.s.l.) (Fig. 1). The meteorological stations are located at approximately the same altitude as the respective tree-ring sampling sites (Fig. 1). The distances between sampling sites and their respective meteorological stations are ca. $100 \mathrm{~km}$. Although the 2 meteorological stations are relatively distant, significant correlations $(p<0.01)$ were found between all records over the period 1958-2008, e.g. monthly precipitation: $r_{\text {mean }}=0.615$ (range from 0.350 to 0.783 ), $p<0.001$; monthly mean temperature: $r_{\text {mean }}=0.931$ (range from 0.843 to $0.970), p<0.001$. Averaging meteorological records from different stations decreases small-scale noise or stochastic variability and improves the statistical relationships between tree-ring and meteorological data (Blasing et al., 1981; Pederson et al., 2001). Thus, the regional mean meteorological data were produced by averaging monthly records of the 2 stations over the interval 1958-2008. Furthermore, standardized means of meteorological data were compared with ring growth, with effectively the same results as for the simply averaged meteorological data. The gridded HadISST1 sea surface temperatures (1870-2008) were downloaded from KNMI Climate Explorer (www.knmi.nl). The relationship between the STD and climate factors (monthly mean temperature and total precipitation) was investigated by simple Pearson correlation analysis. The cold/warm years were identified as exceeding 1 standard deviation (SD) above and below the mean temperature of the period.

\section{Results}

\subsection{Regional climate variability}

During the past 52 years (1957-2008), regional summer (June-August), growth season (May-September) and annual temperatures have increased significantly by $0.047{ }^{\circ} \mathrm{C} /$ year, $0.043^{\circ} \mathrm{C} /$ year and $0.040^{\circ} \mathrm{C} /$ year $\left(0.038^{\circ} \mathrm{C} /\right.$ year for October-April), respectively. Temperature-induced potential evapotranspiration (calculated by the Thornthwaite method) has increased significantly at $0.44 \mathrm{~mm} /$ year and $0.87 \mathrm{~mm} /$ year during the summer season and the whole year, respectively. At the same time, regional mean precipitation has decreased by $0.68 \mathrm{~mm} /$ year, $0.89 \mathrm{~mm} /$ year and $1.20 \mathrm{~mm} / \mathrm{year}$ for the summer season, the whole year and growing season, respectively. The regional mean humidity has decreased significantly by $0.125 \%$ per year, $0.090 \%$ per year and $0.127 \%$ per year for the summer, the whole year and the growth season, respectively. The regional wetness index denoted by the function of $M=(P-P E) / P E$ (where $M, P$ and $P E$ are wetness index, precipitation and potential evapotranspiration, respectively) has decreased. The observations indicate that this region has experienced a clear trend of both drying and warming (Report of Climate Change in Northeast China: I, 2006 (http://www.lnmb.gov.cn/sy_ news_content.asp?ID=2787)).

\subsection{Chronology statistics}

The composite larch tree-ring width chronology is 294 years in length (1715-2008). The series intercorrelation, average mean 
sensitivity, and mean length of series of all raw measurements from Genhe (GH) and Mo'erdaga (MD) are 0.471, 0.261, and 158.0 years, respectively. The EPS for GH and MD is 0.932 (range from 0.846 to 0.984 ) and 0.893 (range from 0.765 to 0.975 ) respectively, and the rBar for GH and MD is 0.265 (range from 0.135 to 0.499 ) and 0.311 (range from 0.111 to 0.666 ), respectively, for 20-year intervals with 10 -year overlaps. Other tree-ring chronology statistics, including the SD (0.192), MS (0.126) and AC1 (0.648), are listed in Table 1. Based on the EPS $>0.85$ criterion, the chronologies have adequate signal strength during their common period (Fig. 3, Table 1). The sample depth of the mean Standard chronology is 10 cores ( 7 trees), the mean effective chronology signal (reff) of GH is 0.351 , and the mean reff of MD is 0.220 , and thus subsample signal strength (SSS) will be close to $0.75(0.70-0.80)$ in 1715 (Briffa and Jones, 1990). The common period has reliable sample depth for regional climate assessment and acceptable signal strength derived from the treering records. In addition, the correlation between $\mathrm{GH}$ and MD chronologies is significant $(r=0.417)$ and their PC1 explanation is high (70.84\%) during period of 1715-1741, the interval of MD's EPS $<0.85$ (Table 1 ). The chronologies described above contain a strong common signal, thus making them suitable for dendroclimatological studies.

\subsection{Climate-growth relationships}

Correlation analysis and multivariate regression were performed for monthly mean temperature and monthly total precipitation over the previous and current years of tree growth. Results show that both temperature and precipitation influence tree growth at this high-latitude region (Fig. 4). The growth-climate responses of individual chronologies and the mean tree-ring chronology from the two regions compared to individual and averaged meteorological records are very similar. The monthly climate data from the E'youqi station are more strongly correlated with tree growth and have higher explained variance for radial growth than the Tulihe station data, attribute to a more typically regional climate regime at E'youqi station (Table 2). The larches at Mo'erdaoga are more sensitive to regional airmass circulation in comparison with that from the Genhe site (Fig. 4, Table 2).

Correlation analysis and multivariate regression results demonstrate that temperature is the limiting climate factor most strongly associated with local larch growth (Fig. 4; Table 2). The temperatures from March to October are positively correlated with tree growth, especially in the month of April, June, July and August $(p<0.05)$. The lag effect of temperature on tree growth denoted by significant correlations between them is apparent (Table 2). Temperatures in the winter (previous November to current January) show weakly negative correlation with tree growth. In the growing season (May-September in the study region), radial growth of larch show very significant correlation with temperature (e.g., $r_{\text {May-Sep }}=0.665, p<0.0001$ ) and it is higher than that $\left(r_{\text {May-Sep }}=0.627\right)$ of the original 2011 data (Zhang et al., 2011a). In contrast, October-April temperature is not significantly correlated with larch growth (e.g., $r_{\text {Oct-Apr }}=0.129, p=0.365$ ), as expected as it is not during the growing period. Correlation coefficients of tree rings and monthly temperature from October to September are significant $(r=0.891, p<0.05)$, but correlations are highest during the growing season, particularly during June, July and August, the warmer months of the year. Tree growth tends to be negatively affected by precipitation during the growing season, and tends to positively correlate to precipitation during the remainder of the year in general (Fig. 4).

Seasonally averaged climatic variables are often more representative of climatic conditions during the growing season than
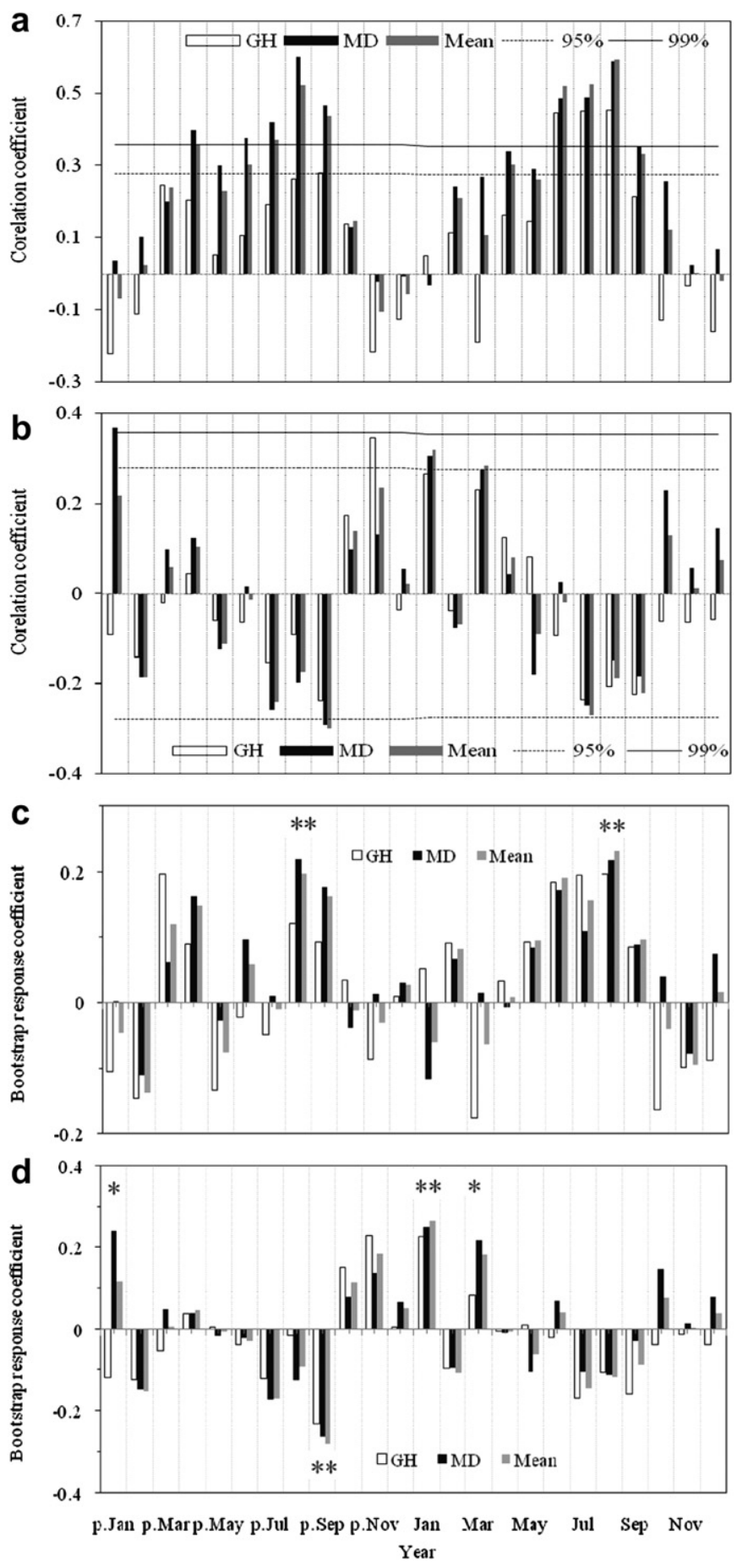

Fig. 4. Correlations (a, b) and bootstrap response coefficients (c, d) (Biondi, 1997; Biondi and Waikul, 2004) of tree rings with mean temperature (a, c) and precipitation (b, d). GH, MD and Mean respectively, denote the correlations/bootstrap response coefficients of tree rings from Genhe, Mo'erdaoga and their mean with averaged temperatures and precipitation from Tulihe and E'youqi (refer to Fig. 1). The black dashed lines are the 95\% confidence limits and the black solid lines are the $99 \%$ confidence limits.*indicates $>95 \%$ percentile range of bootstrap response.

just one single month (Cook et al., 1999). Therefore, different seasonal combinations of temperature for reconstruction were tested. The highest correlation between tree rings and the seasonalized temperature was found in June to August $\left(r_{\text {mean }}=0.686\right.$, $p<0.0001)$. Thus, June to August was chosen as the season for temperature reconstruction. 
Table 2

Climate-explained variance of larch radial growth infer from monthly temperature and rainfall for two calendar years (previous to current year) using multivariate regression analysis.

\begin{tabular}{|c|c|c|c|c|c|c|}
\hline & \multicolumn{2}{|c|}{ E'youqi (\%) } & \multicolumn{2}{|c|}{ Tulihe (\%) } & \multicolumn{2}{|c|}{ Mean (\%) } \\
\hline & Rain & Temperature & Rain & Temperature & Rain & Temperature \\
\hline $\mathrm{GH}$ & 50.4 & 73.1 & 47.5 & 59.0 & 52.7 & 66.0 \\
\hline MD & 75.2 & 76.0 & 53.7 & 66.8 & 68.1 & 72.8 \\
\hline Average & 67.5 & 74.8 & 47.5 & 64.8 & 62.0 & 70.7 \\
\hline
\end{tabular}

GH, MD and Average respectively denote Genhe standard chronology, Mo'erdaoga standard chronology and their arithmetic average; Mean is mean variables of E'youqi meteorological station records and Tulihe meteorological station records.

\subsection{Summer temperature reconstruction}

Based on the above climate-growth analysis, a simple linear regression model was built by calibrating tree rings with June-August temperature (JAT). Over the common period 1957-2008, this model accounted for $47.0 \%$ of the actual temperature variance (Fig. 5). The statistical fidelity of the regression model was examined using split sample calibration-verification tests (Meko and Graybill, 1995) (Table 3). Most of the results for the $t$ statistics of calibration-verification tests for modeled and actual temperatures are significant, and the reduction of error (RE) is positive. Even though the coefficient of efficiency (CE) is sometime negative, its value is close to 0 (e.g. -0.118). The results of calibration-verification tests for the first-difference variables of the reconstructed and actual values show the acceptability of the highfrequency signal in the reconstruction (Table 3 ). The regression model for statistical fidelity was examined using leave-one-out tests (Michaelsen, 1987) with extremely significant results (Table 3).
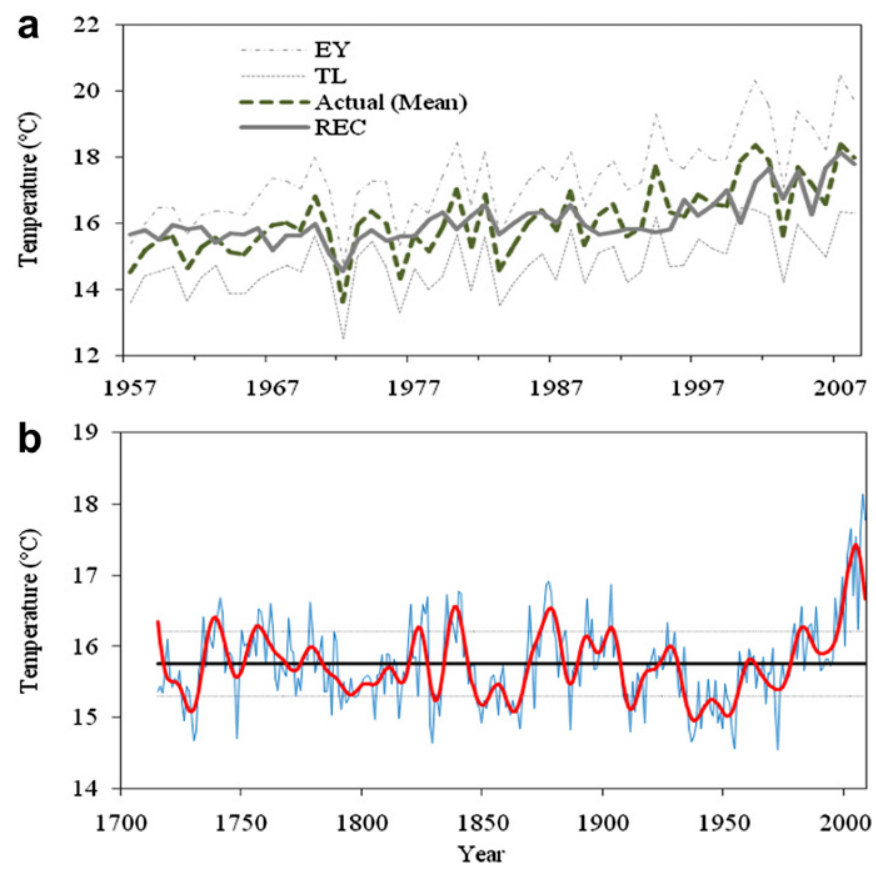

Fig. 5. The comparison between the actual and reconstructed June-August temperature (a) during the common period of 1957-2008, and (b) the reconstructed June-August temperature using the averaged Standard chronologies from 1715 to 2008. In (a), EY, TL, Actual (mean) and REC indicate the data of Tulihe, E'youqi, their mean of TL and EY for regional actual records and reconstruction, respectively; and (b), the thin solid curve is the annually reconstructed June-August temperature, the thin dashed horizontal lines are the top and bottom limits (mean $\pm 1 \sigma$ ) of regional June-August temperature, the thick line indicates average of June-August temperature during the whole period, and the thick curve indicates the smoothed data employing an 11-year low-pass filter.
The reconstructed summer temperature ranges from 14.5 to $18.5^{\circ} \mathrm{C}$ during the latest three centuries (1715-2008). The warmcold criteria of Mean \pm 1 SD ("cold" is $<15.31{ }^{\circ} \mathrm{C}$; "warm" is $>16.22{ }^{\circ} \mathrm{C}$ ) defined 60 cold years $(20.41 \%$ of the total), 53 warm years ( $18.03 \%$ of the total) and 181 normal years ( $61.56 \%$ of the total) in the whole period. Six of the top ten warmest years occurred in recent decades (e.g. 2007, 2008, 2002, 2006, 2004 and 2001).

After adding an 11-year low-pass filter, 10 relatively cold periods and 9 relatively warm periods were identified (Figs. 5 and 6). Here, for a cold/warm period, the temperature must be lower/higher than the mean summer temperature of $15.76{ }^{\circ} \mathrm{C}$ and must continue for at least 5 years. The top 5 cold periods are 1784-1819, 1931-1958, 1844-1868, 1907-1922 and 1718-1733, and the top 5 warm periods are 1978-2008, 1889-1906, 1751-1768, 1869-1883 and 1734-1745. Differences exist in the duration of key cold and warm intervals compared to the original 2011 study, such as the cold period in 1844-1868. In the original study, the cold period was shorter, spanning 1844-1857 and 1931-1958/1930-1949, and warm periods in 1751-1768/1753-1764, 1869-1883/1869-1886 and 1978-2008/1993-2008.

Fourteen relatively cold decades (JAT $<15.76{ }^{\circ} \mathrm{C}$ ) and 16 relatively warm decades (JAT $>15.76{ }^{\circ} \mathrm{C}$ ) were found (Fig. 5). The 1900-1949 and 1750-1799 intervals were the coldest and the warmest half-centuries, respectively. The 19 th century has 24 cold (19 warm) years and its mean JAT is $15.75^{\circ} \mathrm{C}$, which is higher than the mean of 20th century $\left(15.64{ }^{\circ} \mathrm{C}\right)$. Similar to the 2011 study (Zhang et al., 2011a), the 1870s and 2000s were the warmest decades, but the coldest interval (1850-1860) in the 2011 study is not the coldest one in this study.

\section{Discussion}

\subsection{Growth-climate response}

Dahurian larch is the most widespread tree species in Northeast China and Far East Russia (Zyryanova et al., 2007; Vaganov and Kirdyanov, 2010). Its morphological and physiological features allowed it to adapt to severe environmental conditions such as permafrost and frozen conditions, e.g., its superficial root system is capable of forming adventitious roots, it loses its needles each winter, and it assimilates photosynthates rapidly during the very short summer. Larch in permafrost regions is characterized by high sensitivity to temperature and ability to adapt to a tough environment (e.g. cold resistance), similar to other trees whose growth is strongly influenced by temperature (Kirdyanov et al., 2003; Sano et al., 2009; Vaganov and Kirdyanov, 2010). Similar to previously documented results (Vaganov and Kirdyanov, 2010; Zhang et al., 2011a), temperature is one of the main environmental factors that limits tree-ring growth in the high-latitude permafrost region of the Great Xing'an Mountain. The larch ring-width chronology is sensitive to regional temperature anomalies, especially during the summer.

Relatively low annual temperatures and a short growing season highlight the importance of summer temperatures for tree-ring formation in high-latitude Asia (Vaganov and Kirdyanov, 2010). Phenologically, early spring is when bud germination and cell production occur and late autumn is when the growing period ends. Temperatures in spring and autumn determine the length of the growing period and the growth increment of the current year. Temperature and light are more important limiting factors than precipitation when precipitation is sufficient and the evaporation rate is low, especially in permafrost areas (Zhang et al., 2011a).

Morphologically and physiologically, larch in this high latitude region shows a weak response to winter air temperature (October-March, ca. -1.6 to $-28.5{ }^{\circ} \mathrm{C}$ ) because loss of leaves 
Table 3

Statistics for a split calibration-verification procedure.

\begin{tabular}{|c|c|c|c|c|c|}
\hline & Calibration & Verification & Calibration & Verification & Final calibration \\
\hline & $1957-1982$ & 1983-2008 & 1983-2008 & 1957-1982 & 1957-2008 \\
\hline$r$ & $0.477 / 0.367$ & $0.594 / 0.220$ & $0.621 / 0.332$ & $0.480 / 0.328$ & $0.686(0.644-0.722)$ \\
\hline$r^{2}$ & 0.228 & 0.353 & 0.386 & 0.230 & $0.470(0.415-0.521)$ \\
\hline Adjusted $r^{2}$ & 0.196 & & 0.360 & & $0.460(0.403-0.511)$ \\
\hline$F$ & & & & & $44.372(34.740-53.270)$ \\
\hline$p$ & & & & & $<0.000001$ \\
\hline RE & $0.228 / 0.132$ & $0.661 /-0.066$ & $0.386 / 0.064$ & $0.611 / 0.106$ & \\
\hline $\mathrm{CE}$ & $0.228 / 0.132$ & $0.263 /-0.068$ & $0.386 / 0.064$ & $-0.118 / 0.105$ & \\
\hline$t$-Stat & $2.662 * / 1.153$ & $1.249 / 0.328$ & $3.884^{* *} / 0.877$ & $3.044 * * / 0.976$ & \\
\hline
\end{tabular}

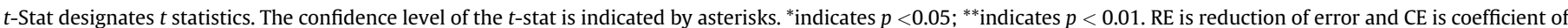

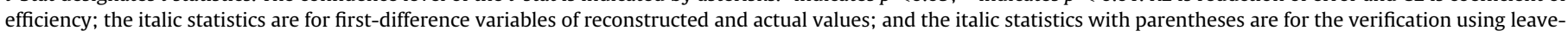
one-out method.

initiates dormancy, in contrast to evergreen conifers, e.g. Pinus sylvestris var. mongolica (Zhang et al., 2011b). Generally, low temperatures in winter could lead to freezing and injury of tree cells and could also damage the shallow roots (Yuan and Li, 1999), which may affect the tree's growth in the following year. Anomalously cold winters could also lead to deep frozen soils and lower ground temperatures. The resulting reduced rate of ground warming and corresponding delay in activation of the root system could shorten the annual growth period of the trees (Wu et al., 2002; Kirdyanov et al., 2003), resulting in narrow growth rings. Low temperatures could also increase the mortality of buds and annotinous branches (Wu et al., 2002; Chen et al., 2008). Correlation coefficients (Fig. 4) indicate that higher than average temperatures can negatively affect larch growth from November to January, the coldest season $\left(-23.1^{\circ} \mathrm{C}\right)$ during deep dormancy. This may be a consequence of an inverse correlation between winter precipitation and winter temperature (e.g. $r_{\text {November }}=-0.362$, $p<0.01$ ). Winter temperatures are inversely correlated with growth in this study area from 1957 to 2008. More snow (winter precipitation) could effectively protect plants from wind and the extremely low winter temperatures more effectively than a thinner snow cover. Snow enhances soil moisture storage, reduces the impacts of water loss through evaporation, and benefits the growth of the following growing season.

\subsection{Cold/warm assessment}

The reconstructions presented herein for the permafrost region of the Great Xing'an Mountains provide a longer time series of summer temperature variability, extending the available instrumental record and tree-ring-based data of Zhang et al. (2011a) by nearly 240 years and 40 years, respectively. The updated reconstruction (June-August) captures a higher percentage of the total variance of the actual temperature records (47\% from the current study vs 39\% from the 2011 work), especially the high-frequency signals, and is more representative of regional humid (forest) climate (Fig. 4). The estimated summer temperature from June to August is significantly correlated with annual mean temperature from January to December of the current year $(r=0.519, p<0.01)$ during 1957-2008, so the estimates of summer temperature from June to August may be representative of annual mean temperature. Furthermore, temperature variations are regionalized by combining two station records. The differences of duration of the key cold/warm intervals between this study and the original 2011 data indicate that by developing more chronologies and a more regional reconstruction, it is possible to reduce the steep or sharp anomalies of temperature amplitudes and detect temperature inter-annual variability and several relatively longer cold (warm) climate intervals.

The full reconstruction shows moderate inter-annual variability throughout the entire 1715-2008 record: e.g., the coefficients of variation $(C V)$ of the reconstructed temperatures range from $-7.6 \%$ to $15.1 \%$; and the deviations $(D E)$ between the reconstruction and instrumental data are small (averaging 3.8\%) during the common period 1957-2008:

$C V=\left(R_{i}-R_{m}\right) / R_{m} \times 100 \%, \quad D E=\left|\left(R_{i}-I_{i}\right) / I_{i}\right| \times 100 \%$

$R_{i}$ and $I_{i}$ are reconstructed temperature and instrumental data at year $i$, respectively, and $R_{m}$ is the average of the reconstructed temperature of the whole period. In the second half of the 20th

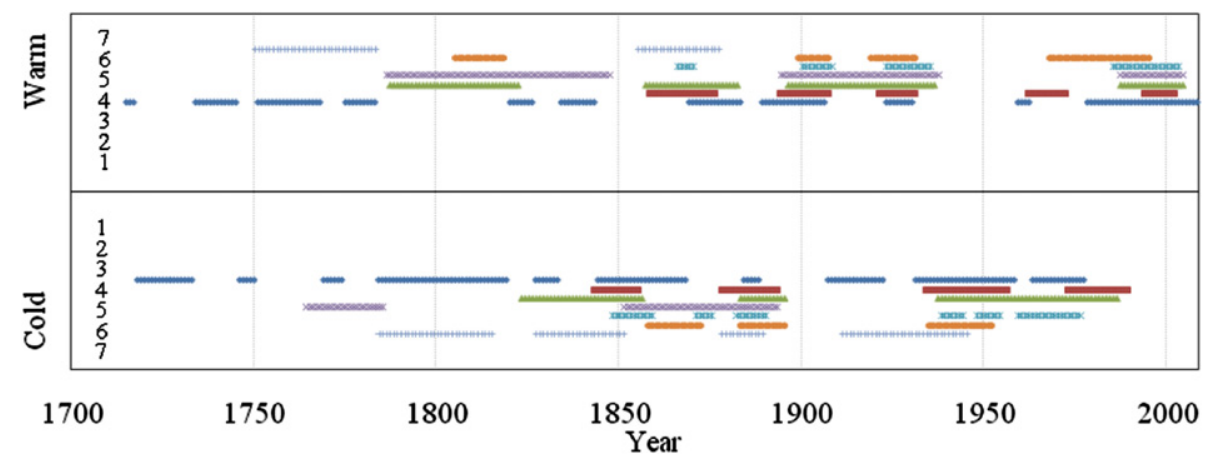

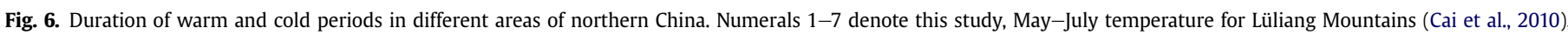

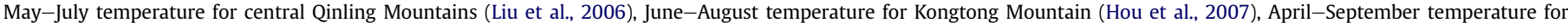

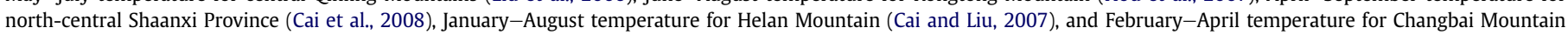
(Zhu et al., 2009). 

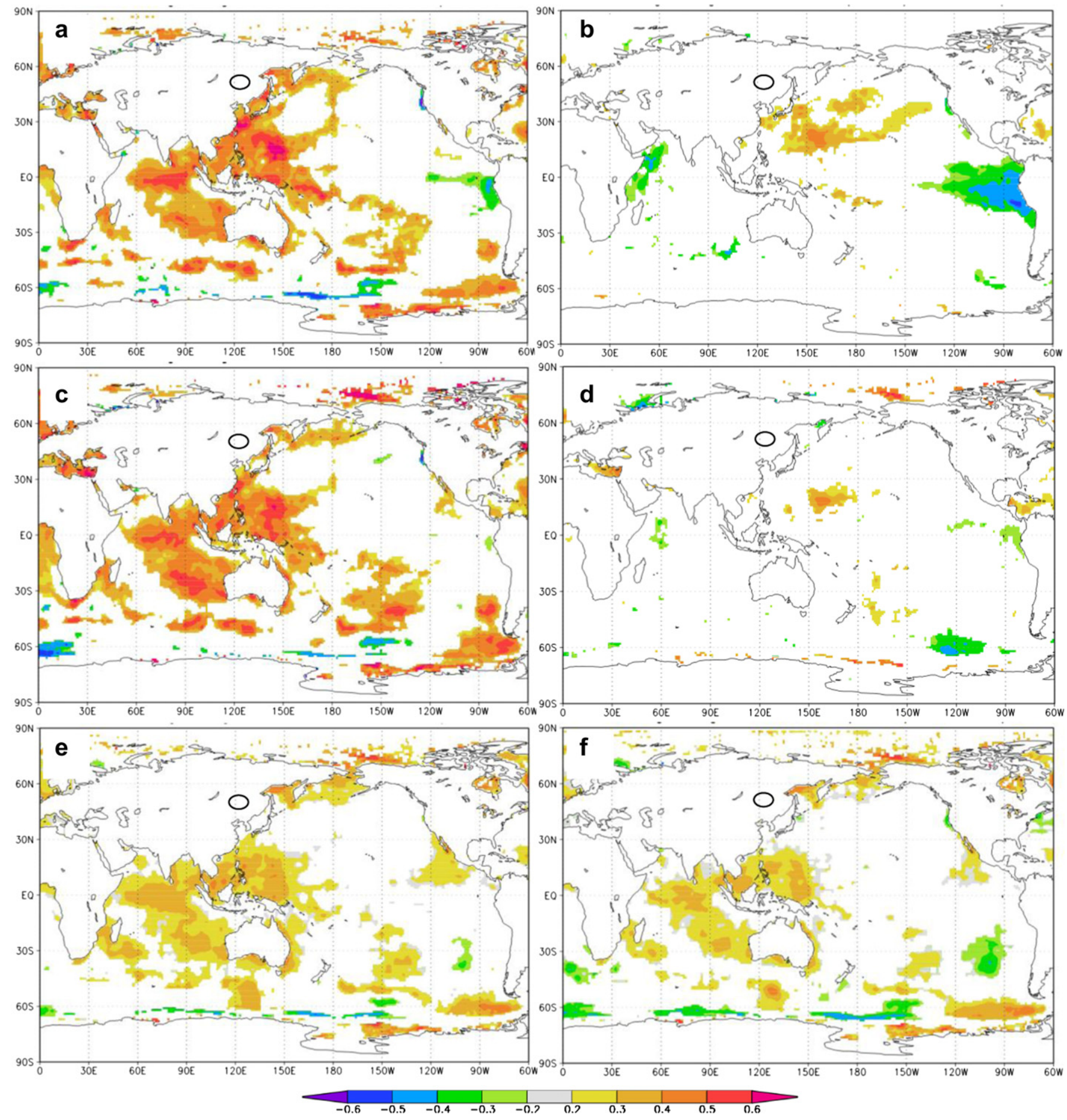

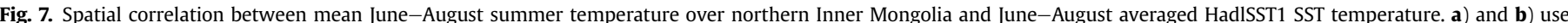

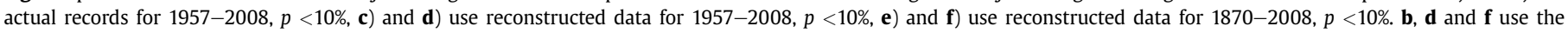

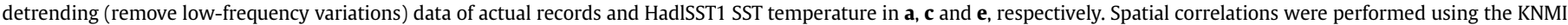
Climate Explorer. The thick circle indicates location of study area.

century the instrumental and tree-ring records are marked by extreme cold summers in 1972 and 2003. Some notable cold years also occurred prior to the instrumental period in 1829, 1936 and 1937 (Wang et al., 2004; Zhang et al., 2011a). At decadal and century time scales, severe cold decades such as the 1850s (Fig. 6) are widely recorded in tree-ring records (Jacoby et al., 1996; Liu et al., 2006; Zhu et al., 2009; Cai et al., 2010; Zhang et al., 2011a).
The reconstruction preserves inter-annual to multi-decadal summer temperature variability (Fig. 6). Two extended cold periods are found from 1741 to 1797 and from 1869 to 1954, and the former occurs during the Little Ice Age (16th-mid 19th century) (Mann, 2002). Decreasing trends in tree-ring width were also detected in the Changbai Mountains in northeastern China during the periods 1750-1816 and 1863-1932 (Zhu et al., 2009). The most 
severe cold periods in other tree-ring-based temperature reconstructions correspond well to the cold/warm periods, particularly 1850s-1860s (Liu et al., 2006; Fan et al., 2009; Cai et al., 2010; Zhang et al., 2011a). Specifically, 1784-1819, a 36-year cold summer period, was a crucial epoch in China's Qing dynasty (1644-1912), when High Qing (1681-1796, also known as "Kang-Qian Golden Age", during which the Qing Dynasty reached the zenith of its social, economical and military power) ended and climate extremes occurred across China (Fan et al., 2009; Zhu et al., 2009; Ge, 2011; Zhang et al., 2011a). This period was also marked by peasant uprisings such as the Later White Lotus Rebellion (1796-1804, towards the end of the Qing Empire) that caused the death of more than 110 million people in China.

The longest warm period from 1978 to 2008 is not local and has regional characteristics consistent with widespread warming (e.g. Jacoby et al., 1996, 2003; Wang et al., 2004; Liu et al., 2006; IPCC, 2007; Fan et al., 2009; Sano et al., 2009; Zhu et al., 2009; Cai et al., 2010; Zhang et al., 2011a). Permafrost ecosystems are very sensitive to temperature variability (Vaganov and Kirdyanov, 2010). The persistent warming has been favorable to Dahurian larch suggesting that there is some complexity and variability in larch forest ecosystem: radial growth increased ca. 33.8\% when temperature increased $1{ }^{\circ} \mathrm{C}$ relative to larch growth in 1957 .

Furthermore, the instrumental and reconstructed records indicate very low summer drought occurrence due to the relative low temperature before AD 2000. However, drought occurred $25 \%$ of the time from 2001 to 2008, the warmest decade in the last 3 centuries.

\subsection{Linkages to East Asia monsoon and tropical Pacific Ocean climate regimes}

This reconstruction covers the Asia monsoon boundary zone, and characterizes a typically continental monsoon climate profile (Yang et al., 1992; Li and Zeng, 2002, 2003). The documented data indicate that cold winters are associated with stronger East Asia winter monsoon climate (Li et al., 2009; Zhu et al., 2009). Consistent with other tree-ring based results (Li et al., 2009; Zhu et al., 2009; Shi et al., 2010), the East Asia monsoon climate regimes also relate to the regional decrease and increase of temperature: e.g., the correlation coefficients of instrumental and reconstructed June-August temperature and East Asian summer monsoon index (1948-2008) (Li and Zeng, 2002, 2003) for June are all significant as $-0.293_{\text {instrumental }}(p<0.05)$ and $-0.324_{\text {reconstructed }}(p<0.05)$. That is, the reconstruction reveals significant variations in the strength of the East Asia summer monsoon over the past three centuries. The cold and warm events are related to strong or weak summer monsoons, respectively, and the cold and warm intervals correspond to strong or weak summer monsoon periods, respectively. For example, the increasing temperatures during the last 50 years are consistent with documented data showing a persistent weakening of the Asia monsoon climate since the 1960s, especially after 1970s (Li et al., 2009), and also supports the findings that the accumulated curves of the zonal wind over the South China Sea are drying (after 1958), which implies a weak monsoon (Fu and Fletcher, 1988; Liu et al., 2003). One possible physical mechanism for shifts in the strength of the monsoon had been proposed by Zhu et al. (2012). They suggest that a strong (northern) East Asian summer monsoon may be related to low pressure around Lake Baikal. At regional scales, the low pressure around the Lake Baikal region can reduce westerly anomalies from the high latitudes and induce a shift in the westerly jet stream to a more southward position. This shift could bring cold air to Northeast China (Zhu et al., 2012).

Regional climate variability and local tree growth are greatly influenced by the Pacific Ocean (He et al., 2007; Li et al., 2009; Zhu et al., 2009; Chen et al., 2011). For example, northern hemisphere zonal circulation variables, which dominates local climate variability and ecosystem succession, could be defined using the normalized zonal mean sea-level pressure of the Pacific Ocean at high latitude (e.g. $\geq 60^{\circ} \mathrm{N}$ ) (Wang, 2006). Also, the SSTs of the western Pacific Ocean and northeastern Indian Ocean significantly correlate with June-August temperature of the study area (Fig. 7) suggesting the potential influences of ENSO (El Niño/La NiñaSouthern Oscillation). Furthermore, the prevailing "cool" PDO regimes from 1900 to 1924 and from 1947 to 1976 and the dominant "warm" PDO regimes from 1925 to 1946 and from 1977 to the mid-1990's (Mantua and Hare, 2002) correspond broadly to most of the cold and warm periods (Figs. 5 and 6).

\section{Acknowledgments}

This work was funded by the National Natural Science Foundation of China Project 41071035, 31100327, 30600093, 31000225, 31000222 and 31170573 . The work was also supported by the National Science Foundation, USA (NSF) AGS-PRF1137729. We would like to thank the Committee ADA2011 for help on this paper. We also thank Dr. Steven W. Leavitt and the two anonymous reviewers for their constructive comments.

\section{References}

Biondi, F., 1997. Evolutionary and moving response functions in dendroclimatology Dendrochronologia 15, 139-150.

Biondi, F., Waikul, K., 2004. DENDROCLIM2002: AC ++ program for statistical calibration of climate signals in tree-ring chronologies. Computers in GeosciencesUK 30, 303-311.

Blasing, T.J., Duvick, D.N., West, D.C., 1981. Calibration and verification using regionally averaged single station precipitation data. Tree-Ring Bulletin 41, $37-44$.

Briffa, K., Jones, P.D., 1990. Basic chronology statistics and assessment. In: Cook, E., Kairiukstis, L.A. (Eds.), Methods of Dendrochronology: Applications in the Environmental Sciences. Kluwer Academic Publishers, Boston, pp. 137-152.

Cai, Q.F., Liu, Y., 2007. January to August temperature variability since 1776 inferred from tree-ring width of Pinus tabulaeformis in Helan Mountains. Journal of Geography Science 17, 293-303.

Cai, Q.F., Liu, Y., Song, H.M., Sun, J.Y., 2008. Tree-ring-based reconstruction of the April to September mean temperature since 1826AD for north-central Shaanxi Province, China. Science in China Series D - Earth Sciences 51, 1099-1106.

Cai, Q.F., Liu, Y., Bao, G., Lei, Y., Sun, B., 2010. Tree-ring-based May-July mean temperature history for Lüliang Mountains, China, since 1836. Chinese Science Bulletin 55 (3), 1-8.

Chen, Z., Zhang, X., Cui, M., He, X., Ding, W., Peng, J., 2012. Tree-ring based precipitation reconstruction for the forest-steppe ecotone in northern Inner Mongolia, China and its linkages to the Pacific Ocean variability. Global and Planetary Change 86-87, 45-56.

Chen, Z.J., He, X.Y., Cook, E.R., He, H.S., Chen, W., Sun, Y., Cui, M.X., 2011. Detecting dryness and wetness signals from tree rings in Shenyang, Northeast China. Palaeogeography, Palaeoclimatology, Palaeoecology 302, 301-310.

Chen, Z.J., Sun, Y., He, X.Y., Chen, W., Shao, X.M., Zhang, H.Y., Wang, Z.Y., Liu, X.Y., 2008. Chinese pine tree ring width chronology and its relation to climate conditions in the Qianshan Mountains. Frontiers of Forestry in China 3 (4), 381-392.

Cook, E.R., 1985. A Time-series Analysis Approach to Tree-ring Standardization, PhD dissertation, The University of Arizona, Tucson.

Cook, E.R., Holmes, R.L., 1986. Users manual for program ARSTAN. In: Holmes, R.L. Adams, R.K., Fritts, H.C. (Eds.), Tree-ring Chronologies of Western North America: California, Eastern Oregon and Northern Great Basin. Chronology, vol. 6. The University of Arizona, Tucson, pp. 50-65.

Cook, E.R., Meko, D.M., Stahle, D.W., Cleaveland, M.K., 1999. Drought reconstructions for the continental United States. Journal of Climate 12, 1145-1162.

Davi, N.K., Jacoby, G.C., Curtis, A.E., Baatarbileg, N., 2006. Extension of drought records for central Asia using tree rings: west-central Mongolia. Journal of Climate 19, 288-299.

D’Arrigo, R., Jacoby, G., Frank, D., Pederson, N., Cook, E., Buckley, B., Nachin, B. Mijiddorj, R., Dugarjav, C., 2001. 1738 years Of Mongolian temperature variability inferred from a tree ring record of Siberian pine. Geophysical Research Letters 28, 543-546.

Fan, Z.X., Bräuning, A., Yang, B., Cao, K.F., 2009. Tree ring density-based summer temperature reconstruction for the central Hengduan Mountains in Southern China. Global and Planetary Change 65, 1-11.

Fritts, H.C., 1976. Tree Rings and Climate. Academic Press, London. 
Fu, C.B., Fletcher, J., 1988. Large signal of climatic variation over the ocean in the Asian monsoon region. Advances in Atmospheric Sciences 5, 389-404.

Ge, Q.S., 2011. The Climate Change in China During the Past Dynasties. Science Press, Beijing.

Harris, C., Arenson, L.U., Christiansen, H.H., Etzelmüller, B., 2009. Permafrost and climate in Europe: monitoring and modelling thermal, geomorphological and geotechnical responses. Earth-Science Reviews 92, 117-171.

He, X.Y., Chen, Z.J., Chen, W., Shao, X.M., He, H.S., Sun, Y., 2007. Solar activity, global surface air temperature anomaly and Pacific Decadal Oscillation recorded in urban tree rings. Annals of Forest Science 64, 743-756

Holmes, R.L., 1983. Computer-assisted quality control in tree-ring dating and measurement. Tree-Ring Bulletin 43, 69-95.

Hou, Y., Wang, N.A., Li, G., Zheng, F., 2007. Reconstruction of summer average temperature from tree-ring proxy data during 1751-2005 in Mt. Kongtong (in Chinese). Advances in Climate Change Research 3, 172-176.

IPCC (Intergovernmental Panel on Climate Change), 2007. Climate Change 2007: Synthesis Report, Cambridge University Press, Cambridge.

Jacoby, G.J., D’Arrigo, R.D., Davaajamts, T., 1996. Mongolian tree rings and 20thcentury warming. Science $273,771-773$.

Jacoby, G., Pederson, N., D'Arrigo, R., 2003. Temperature and precipitation in Mongolia based on dendroclimatic investigations. Chinese Science Bulletin 48 (14), 1474-1479.

Jin, H.J., Li, S.X., Cheng, G.D., Garfin, G.M., 2000. Permafrost and climatic change in China. Global and Planetary Change 26, 387-404.

Kääb, A., Chiarle, M.R.B., 2007. Climate change impacts on mountain glaciers and permafrost. Global and Planetary Change 56, vii-ix.

Kirdyanov, A., Hughes, M., Vaganov, E., Schweingruber, F., Silkin, P., 2003. The importance of early summer temperature and date of snow melt for tree growth in the Siberian Subarctic. Trees - Structure and Function 17, 61-69.

Li, J., Zeng, O., 2002. A unified monsoon index. Geophysical Research Letters 29 (8), 1274. http://dx.doi.org/10.1029/2001GL013874.

Li, J., Zeng, Q., 2003. A new monsoon index and the geographical distribution of the global monsoons. Advances in Atmospheric Sciences 20, 299-302.

Li, J., Cook, E.R., D'arrigo, R., Chen, F., Gou, X., 2009. Moisture variability across China and Mongolia: 1951-2005. Climate Dynamics 32, 1173-1186.

Liang, E.Y., Shao, X.M., Liu, H.Y., Eckstein, D., 2007. Tree-ring based PDSI reconstruction since AD 1842 in the Ortindag Sand Land, East Inner Mongolia. Chinese Science Bulletin 52 (19), 2715-2721.

Liu, Y., Bao, G., Song, H., Cai, Q., Sun, J., 2009. Precipitation reconstruction from Hailar pine (Pinus sylvestris var. mongolica) tree rings in the Hailar region, Inner Mongolia, China back to 1865 AD. Palaeogeography, Palaeoclimatology, Palaeoecology 282, 81-87.

Liu, Y., Linderholm, H.W., Song, H., Cai, Q., Tian, Q., Sun, J., Chen, D., Simelton, E. Seftigen, K., Tian, H., Wang, R., Bao, G., An, Z., 2006. Temperature variation recorded in Pinus tabulaeformis tree rings from the southern and northern slopes of the central Qinling Mountains, central China. Boreas 38, 285-291.

Liu, Y., Park, W.K., Cai, Q., Seo, J.W., Sook, J.H., 2003. Monsoonal precipitation variation in the East Asia since A.D. 1840 - tree-ring evidences from China and Korea. Science in China Series D - Earth Sciences 46, 1031-1039.

Liu, Y., Sun, J., Yang, Y., Cai, Q., Song, H., Shi, J., An, Z., Li, X., 2007. Tree-ring-derived precipitation records from Inner Mongolia, China, since A.D. 1627. Tree-Ring Research 63 (1), 3-14

Liu, Y., Tian, H., Song, H., Liang, J., 2010. Tree ring precipitation reconstruction in the Chifeng-Weichang region, China, and East Asian summer monsoon variation since A.D. 1777. Journal of Geophysical Research 115, 1-9. http://dx.doi.org/ 10.1029/2009JD012330.

Mann, M.E., 2002. Little Ice Age, volume 1, the earth system: physical and chemica dimensions of global environmental change. In: MacCracken, M.C., Perry, J.S. (Eds.), Encyclopedia of Global Environmental Change. John Wiley \& Sons, Ltd, Chichester, pp. 504-509.

Mantua, N.J., Hare, S.R., 2002. The Pacific Decadal Oscillation. Journal of Oceanography $58,35-44$.

Meko, D.M., Graybill, D.A., 1995. Tree-ring reconstruction of Upper Gila river discharge. Water Resources Bulletin 31, 605-616.
Michaelsen, J., 1987. Cross validation in statistical climate forecast models. Journal of Climate and Applied Meteorology 26, 1589-1600.

Osterkamp, T.E., 2005. The recent warming of permafrost in Alaska. Global and Planetary Change 49, 187-202.

Pederson, N., Jacoby, G.C., D’Arrigo, R., Cook, E.R., Buckley, B.M., Dugarjav, C. Mijiddorj, R., 2001. Hydrometeorological reconstructions for northeastern Mongolia derived from tree rings: AD 1651-1995. Journal of Climate 14, 872-881.

Sano, M., Furuta, F., Sweda, T., 2009. Tree-ring-width chronology of Larix gmelinii as an indicator of changes in early summer temperature in east-central Kamchatka. Journal of Forestry Research 14, 147-154.

Shao, X.M., Wu, X.D., 1997. Reconstruction of climate change on Changbai Mountain, Northeast China using tree-ring data. Chinese Quaternary Science 1, 76-85.

Shi, J.F., Cook, E.R., Lu, H.Y. Li, J.B., Wright, W.E., Li, S.F. 2010. Tree-ring based winter temperature reconstruction for the lower reaches of the Yangtze River in Southeast China. Climate Research 41, 169-175.

Stokes, M.A., Smiley, T.L., 1968. An Introduction to Tree Ring Dating. The University of Chicago Press, Chicago.

Sun, G.Y., Yu, S.P., Wang, H.X., 2007. Causes, south borderline and subareas of permafrost in Da Hinggan mountains and Xiao Hinggan Mountains. Sciatica Geographic Sinica 27, 68-74.

Vaganov, E.A., Kirdyanov, A.V., 2010. Dendrochronology of larch trees growing on Siberian permafrost. In: Osawa, A. (Ed.), Permafrost Ecosystems: Siberian Larch Forests. Ecological Studies, vol. 209, pp. 347-363.

Vaganov, E.A., Shiyatov, S.G., Mazepa, V.S., 1996. Dendroclimatic Investigation in Ural-Siberian Subarctic. Nauka, Novosibirsk.

Wang, H., 2006. Linkage between the Northeast Mongolian precipitation and the northern hemisphere zonal circulation. Advances in Atmospheric Sciences 23 (5), 659-664

Wang, S., Zhu, J., Cai, J., 2004. Interdecadal variability of temperature and precipitation in China since 1880. Advances in Atmospheric Sciences 21 (3), 307-313.

Wigley, T., Briffa, K.R., Jones, P.D., 1984. On the average value of correlated time series, with applications in dendroclimatology and hydrometeorology. Journal of Climate and Applied Meteorology 23, 201-213.

Wu, F.Z. Zhao, W., Sun, M.Q. Xu, S.H., 2002. Influence of low temperature on Pinus thunbergii Parl. needles and branches. Journal of Shenyang Agricultural University 33 (3), 178-181.

Yang, G., Chen, X., Zhou, D., 1992. Ordination and gradient analysis of coniferous forest in Daxinganling. Journal of Northeast Forestry University 3 (1), 42-47.

Yatagai, A., 2003. Evaluation of hydrological balance and its variability in arid and semi-arid regions of Eurasia from ECMWF 15 year reanalysis. Hydrological Processes 17, 2871-2884. http://dx.doi.org/10.1002/hyp.1439.

Yuan, Y.J., Li, J.F., 1999. Reconstruction and analysis of 450 years' winter temperature series in Ürümqi river source of Tianshan Mountains. Journal of Glaciology and Geocryology 21 (1), 64-70.

Zhang, X.L., He, X.Y., Chen, Z.J., Cui, M.X., Li, N., 2011b. Response of Pinus sylvestris var. mongolica radial growth to climate warming on Great Xing'an Mountain: a case in Mangui. Chinese Journal of Applied Ecology 22 (12), 1-13.

Zhang, X.L., He, X.Y., Li, J.B., Davi, N., Chen, Z.J., Cui, M.X., Chen, W., Li, N., 2011a. Temperature reconstruction (1750-2008) from Dahurian larch tree-rings in an area subject to permafrost in Inner Mongolia, Northeast China. Climate Research 47, 151-159. http://dx.doi.org/10.3354/cr00999.

Zhou, M., Yu, X., Feng, L., 2002. Analysis on the driving force of the permafrost degeneration in Daxinganling. Journal of Arid Land Resource and Environment $16,44-47$.

Zhu, C., Wang, B., Qian, W., Zhang, B., 2012. Recent weakening of northern East Asian summer monsoon: a possible response to global warming. Geophysical Research Letters 39, L09701. http://dx.doi.org/10.1029/2012GL051155.

Zhu, H.F., Fang, X.Q., Shao, X.M., Yin, Z.Y., 2009. Tree ring-based February-April temperature reconstruction for Changbai Mountain in Northeast China and its implication for East Asian winter monsoon. Climate of the Past 5, 661-666.

Zyryanova, O.A., Yaborov, V.T., Tchikhachva, T.L., Koike, T., Makoto, K., Matsuura, Y., Satoh, F. Zyryanov, V.I., 2007. The structure and biodiversity after fire disturbance in Larix gmelinii (Rupr.) Rupr. forests, northeastern Asia. Eurasian Journal of Forest Research $10(1), 19-29$. 